\title{
Insulin Sensitizing and Antiatherogenic Role of Adiponectin: A Cross Sectional Study among the Healthy Subjects in Kerala
}

\author{
Dr. Manju K Sudharmadevi ${ }^{* 1}$, Dr. Leena K Balakumaran ${ }^{2}$, Dr. Vijayalekshmi Lekshminarayan ${ }^{3}$, \\ Dr. Shenoy K Trivikrama ${ }^{4}$
}

${ }^{1}$ Associate Professor, Department of Biochemistry, Sree Gokulam Medical College and Research Foundation, Trivandrum, Kerala, India-695607

${ }^{2}$ Senior Research Scientist, Population Health and Research Institute, Medical College P.O, Trivandrum, Kerala, India- 695011

${ }^{3}$ Prof.\& Head (Rtd), Department of Applied Nutrition, Govt. Medical College, Trivandrum, Kerala, India-695011

${ }^{4}$ Prof. \& Head, Dept of Gastroenterology, Sree Gokulam Medical College and Research Foundation, Trivandrum, Kerala, India-695607

*Corresponding author: Dr. Manju K Sudharmadevi; manjuromel@gmail.com

Received 11 November 2021;

Accepted 27 November 2021;

Published 01 December 2021

\begin{abstract}
Background of the study and objectives: Adiponectin, the most abundantly secreted adipokine plays a central role in energy homeostasis. Different studies have reported the protective role of adiponectin in obesity related complications such as insulin resistance, hypertension, dyslipidemia, atherosclerosis etc. Since not much studies were conducted to analyze the role of adiponectin in the metabolic homeostasis among the healthy population in Kerala, we designed this study. Materials and methods: This study included 170 healthy subjects of both gender in the age group of 20-60 years. Anthropometric measurements and blood pressure were recorded. BMI, WHR and BF\% were calculated. Fasting blood sample was used to measure glucose, lipid profile, insulin and adiponectin. HOMA-IR, HOMA- $\beta$ and QUICKI were calculated. Data was analyzed by student's ' $\mathrm{t}$ ' test and pearson's correlation analysis. $\mathrm{p}<0.05$ was considered statistically significant. $\underline{\text { Results: }}$ Serum adiponectin showed a negative correlation with BMI $(\mathrm{r}=-0.583)$ and body fat percentage $(\mathrm{r}=-0.369)$. An inverse significant correlation of adiponectin with serum triglycerides $(\mathrm{p}=0.01)$, fasting glucose $(\mathrm{p}=0.01)$ and HOMA-IR $(\mathrm{p}=0.001)$ was observed. But insulin sensitivity (QUICKI) ( $=0.001)$ and serum HDL-cholesterol $(\mathrm{p}=0.01)$ showed a significant positive correlation with adiponectin. Analysis of the study subjects based on BMI showed a significant decrease in serum adiponectin $(\mathrm{p}=0.001)$ among obese group in comparison with normal weight subjects. Hypoadiponectinemia among obese subjects was also found to be associated with insulin resistance and decreased insulin sensitivity expressed as QUICKI. Conclusion: Serum adiponectin showed a positive correlation with insulin sensitivity and HDL-cholesterol. Adiponectin retains a significant role as a mediator of insulin resistance and atherosclerosis.
\end{abstract}

Keywords: Adiponectin, insulin resistance, HDL-cholesterol, Obesity, Kerala

\section{Introduction}

Adiponectin, a $30 \mathrm{kD}$ cytokine peptide hormone with 244 amino acids mainly synthesized and secreted by adipocytes. It is the most abundantly secreted adipokine constituting $0.01 \%$ of total plasma proteins which is about thousand times that of other major adipokines such as leptin and ghrelin ${ }^{[1]}$. Serum adiponectin levels are found to be inversely associated with measures of obesity which forms the major health issues strongly increasing the risk of many metabolic complications with increased morbidity and mortality such as metabolic syndrome, cardiovascular diseases, respiratory disorders, diabetes, cancer etc. ${ }^{[2,3]}$. Insulin resistance is a key feature of the metabolic complications developed due to increased body fat. While most adipokines are proinflammatory in action, adiponectin exhibits anti-inflammatory, anti-atherogenic, antioxidative as well as insulin sensitizing properties ${ }^{[4-6]}$ which focus the critical role of adiponectin in the maintenance of metabolic homeostasis ${ }^{[7]}$. 
In contrast to other adipokines, low circulating levels of adiponectin are reported to be a strong risk factor for the development of insulin resistance which contribute to diabetes mellitus, metabolic syndrome, coronary artery diseases etc. ${ }^{[8,9]}$. Various studies have been conducted to analyse the antiinflammatory and anti- atherogenic role of adiponectin as well as the role in energy homeostasis and metabolism of carbohydrates and lipids. The inverse relationship between serum adiponectin and insulin resistance in several pathological conditions with high cardiovascular risk such as obesity, diabetes, metabolic syndrome etc. has been established ${ }^{[10,11]}$.

Adiponectin circulates in plasma as three different multimeric complexes with different molecular weight which differ in the biological functions ${ }^{[12]}$. The high molecular weight polymeric form was identified as the biologically active form of this adipokine ${ }^{[13]}$. Adiponectin exerts its physiological functions by binding with two receptors, AdipoR1 and AdipoR2. AdipoR2 has been found to be expressed mainly in liver while AdipoR1 present in almost all tissues ${ }^{[14]}$. Studies reported that in obesity linked insulin resistance, both adiponectin and adiponectin receptors are down regulated ${ }^{[15,16]}$. Due to the unique body composition and structure characterized by increased fat accumulation even at low BMIs, Indians have an increased incidence of metabolic complication diabetes even at normal BMI but with increased waist to hip ratio. This factor makes the population highly predisposed to metabolic syndrome. The present study was undertaken to analyse the role of adiponectin in predicting the incidence of insulin resistance and thus diabetes and metabolic syndrome among the healthy adult population. Since most of the studies designed to elucidate the role of adiponectin in metabolic complications have been conducted in animal models as well as humans with metabolic disorders, we designed this crosssectional study among the healthy subjects.

\section{Study subjects and Methods}

This observational, cross -sectional study was jointly conducted at Govt. Medical College, Thiruvananthapuram and Sree Gokulam Medical college and Research Foundation, Thiruvananthapuram, Kerala, India after obtaining the approval from Human Ethics Committee from both Institutions. One hundred and seventy (87 men and 83 women) healthy volunteers aged between 20-60years were recruited to this study. Subjects with a history of drug intake affecting the study variables and those with any of the endocrine disorders were excluded from the study. Pregnant and postpartum women and those taking oral contraceptive pills were excluded.
A detailed informed consent was obtained from each subject. All participants answered a life style questionnaire to record demographic and socio economic details, life style habits, detailed clinical history and the data were confidential. Anthropometric measurements and blood pressure were recorded. Body Mass Index (BMI), Body fat percentage (BF\%) and waist to hip ratio (WHR) were calculated using anthropometric measurements. Fasting blood sample was used to measure the biochemical parameters. Blood glucose and lipid profile was done in 'Siemens Dimension' fully autoanalyzer using Flex reagent cartridges. Serum adiponectin (Bio Vendor Cat. No. RD195023100) (17) and insulin (DRG Cat No: EIA 2935) ${ }^{[18]}$ were measured by ELISA sandwich method according to the manufacturer's instructions.

Markers of insulin resistance such as Homeostasis model assessment of insulin resistance HOMA-IR ${ }^{[19]}$, Homeostasis model assessment of insulin secretion by beta cells of pancreas (HOMA$\beta)^{[19]}$ and Insulin sensitivity expressed as Quick Insulin sensitivity Check Index (QUICKI) ${ }^{[20]}$ were calculated as previously defined from fasting glucose and insulin values using standard equations. Data was presented as mean \pm SEM and were analysed using Statistical Package for Social Sciences (SPSS) for Windows version 17.0 (SPSS Inc, Chicago, IL, USA). Correlation of serum adiponectin with markers of insulin resistance and lipoproteins were analyzed by Pearson's correlation. To analyze the role of adiponectin in the development of metabolic complications relating insulin resistance, the study population was grouped based on BMI and analyzed the data by unpaired Student's ' $t$ ' test. The statistical significance was defined by $\mathrm{p}<0.05$.

\section{Results}

Serum adiponectin showed a statistically significant $(\mathrm{p}<0.001)$ negative correlation with BMI $(\mathrm{r}=-0.583)$, waist circumference $(\mathrm{r}=$ -0.498), hip circumference $(r=-0.470)$, WHR $(r=-0.3)$ and body fat $(\mathrm{r}=-0.337)$ and serum triglycerides $(\mathrm{r}=-0.189, \mathrm{p}<0.01)$ while no significant correlation was observed with serum total cholesterol and LDL-cholesterol levels (Table1). But statistically significant positive correlation was observed between adiponectin and HDLcholesterol $(r=0.206, p<0.01)$ indicating the anti- atherogenic role of adiponectin. A significant negative correlation of serum adiponectin observed with serum insulin and insulin resistance expressed as HOMA-IR ( $\mathrm{p}=0.001$ ) (Fig1), while a significant positive correlation observed with insulin sensitivity expressed as QUICKI ( $r=0.417, \mathrm{p}=0.001$ ) (Fig2).No statistically significant correlation was observed between serum adiponectin and the rate of synthesis of insulin expressed as HOMA- $\beta$ (Table1).

Table 1: Correlation of serum adiponectin with study variables

\begin{tabular}{|l|l|l|}
\hline Study variable & r & p value \\
\hline Weight $(\mathrm{Kg})$ & -0.508 & 0.001 \\
\hline Height $(\mathrm{cm})$ & 0.047 & NS \\
\hline BMI $\left(\mathrm{Kg} / \mathrm{m}^{2}\right)$ & -0.583 & 0.001 \\
\hline Waist circumference $(\mathrm{cm})$ & -0.498 & 0.001 \\
\hline Hip circumference $(\mathrm{cm})$ & -0.470 & 0.001 \\
\hline Waist to Hip Ratio $(\mathrm{WHR})$ & -0.297 & 0.001 \\
\hline Body Fat $(\%)$ & -0.337 & 0.001 \\
\hline Fasting plasma Glucose $(\mathrm{mg} / \mathrm{dl})$ & -0.180 & 0.01 \\
\hline Total cholesterol $(\mathrm{mg} / \mathrm{dl})$ & -0.043 & NS \\
\hline Triglycerides $(\mathrm{mg} / \mathrm{dl})$ & -0.189 & 0.01 \\
\hline HDL-Cholesterol $(\mathrm{mg} / \mathrm{dl})$ & 0.206 & 0.01 \\
\hline LDL-Cholesterol $(\mathrm{mg} / \mathrm{dl})$ & -0.030 & $\mathrm{NS}$ \\
\hline Serum Insulin $(\mu \mathrm{IU} / \mathrm{ml})$ & -0.392 & 0.001 \\
\hline
\end{tabular}




\begin{tabular}{|l|l|l|}
\hline HOMA -IR & -0.369 & 0.001 \\
\hline HOMA $-\beta$ & -0.073 & 0.05 \\
\hline QUICKI & 0.417 & 0.001 \\
\hline
\end{tabular}

Data analyzed by pearson's correlation. $p<0.05$ considered statistically significant. NS-Not Significant

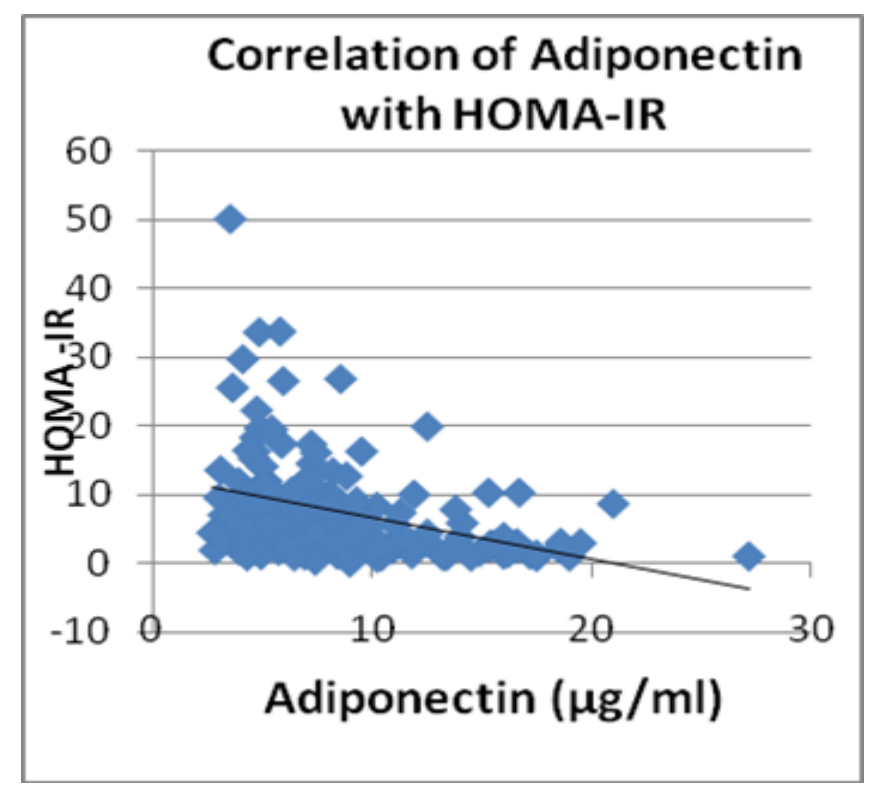

Fig1: Correlation of adiponectin with HOMA-IR

In order to analyze the role of adiponectin in the regulation of body fat mass and metabolic homeostsis we grouped the study subjects in to two (case and control) based on BMI with a cutoff point of 25 $\mathrm{kg} / \mathrm{m}^{2}$. The mean BMI of case (obese group) was $29.3 \mathrm{~kg} / \mathrm{m}^{2}$ and that of control group was $21.5 \mathrm{~kg} / \mathrm{m}^{2}$ (Table 2). There was no statistically significant difference in age between the two groups.

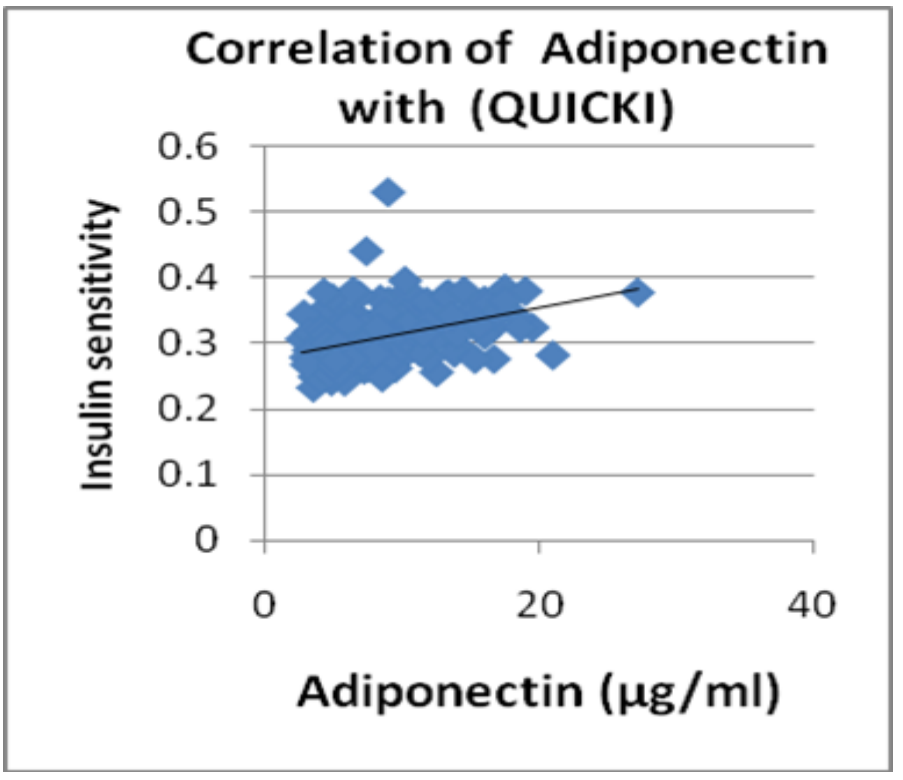

Fig2: Correlation of adiponectin with Insulin sensitivity

Waist circumference and body fat percentage showed a statistically significant difference $(\mathrm{p}=0.001)$ between the two groups. The serum adiponectin level $(\mu \mathrm{g} / \mathrm{ml})$ was found to be decreased significantly $(\mathrm{p}=0.001)$ in obese group $(6.28 \pm 2.05)$ compared to control group (11.95 \pm 4.65$)$.

Table 2: Adiposity measures and serum Adiponectin based on BMI

\begin{tabular}{|l|l|l|l|}
\hline Study variable & Control $(\mathbf{n}=\mathbf{7 1})$ & Obese $(\mathbf{n}=99)$ & p value \\
\hline Age $(\mathrm{yrs})$ & $37 \pm 11.8$ & $42.4 \pm 10.8$ & NS \\
\hline Weight $(\mathrm{kg})$ & $57.5 \pm 9.6$ & $76.1 \pm 10.6$ & 0.001 \\
\hline Height $(\mathrm{cm})$ & $163.4 \pm 9.4$ & $161.1 \pm 8.2$ & NS \\
\hline BMI $\left(\mathrm{kg} / \mathrm{m}^{2}\right)$ & $21.5 \pm 2.4$ & $29.3 \pm 3.9$ & 0.001 \\
\hline Waist circumference $(\mathrm{cm})$ & $82.4 \pm 8.7$ & $100.45 \pm 9.1$ & 0.001 \\
\hline Hip circumference $(\mathrm{cm})$ & $90.3 \pm 8.0$ & $105.8 \pm 7.9$ & 0.001 \\
\hline WHR & $0.91 \pm 0.04$ & $0.95 \pm 0.05$ & 0.001 \\
\hline Body Fat $(\%)$ & $25.6 \pm 7.0$ & $37.4 \pm 8.9$ & 0.001 \\
\hline Serum adiponectin $(\mu \mathrm{g} / \mathrm{ml})$ & $11.95 \pm 4.65$ & $6.28 \pm 2.05$ & \\
\hline
\end{tabular}

Data expressed as mean \pm SEM analysed by student's ' $t$ ' test. $P<0.05$ considered significant

Serum insulin level $(\mu \mathrm{IU} / \mathrm{ml})$ was found to be elevated significantly among obese subjects $(36.79 \pm 2.3$, mean \pm SEM) compared with control $(16.6 \pm 2.0$, mean $\pm \mathrm{SEM})(\mathrm{p}=0.001)($ Fig 3). No statistically significant difference observed in fasting plasma glucose between the groups. There was no statistically significant difference in the rate of insulin synthesis expressed as HOMA- $\beta$ between the two groups (Fig 4). In terms of BMI, this study showed a statistically significant increase in insulin resistance
(HOMA-IR) (Fig 5) with a significant decrease in insulin sensitivity (QUICKI) (Fig 6) in obese group (BMI $>=25 \mathrm{~kg} / \mathrm{m}^{2}$ ) compared to control group $\left(\mathrm{BMI}<=24.9 \mathrm{~kg} / \mathrm{m}^{2}\right)$ Insulin resistance expressed as HOMA-IR was strongly associated with obese group $(9.86 \pm 0.79)$ in comparison with control group $(3.8 \pm 0.45)$. Insulin sensitivity expressed as QUICKI showed a significant decrease in obese group in comparison with control group $(\mathrm{p}=0.001)$. 


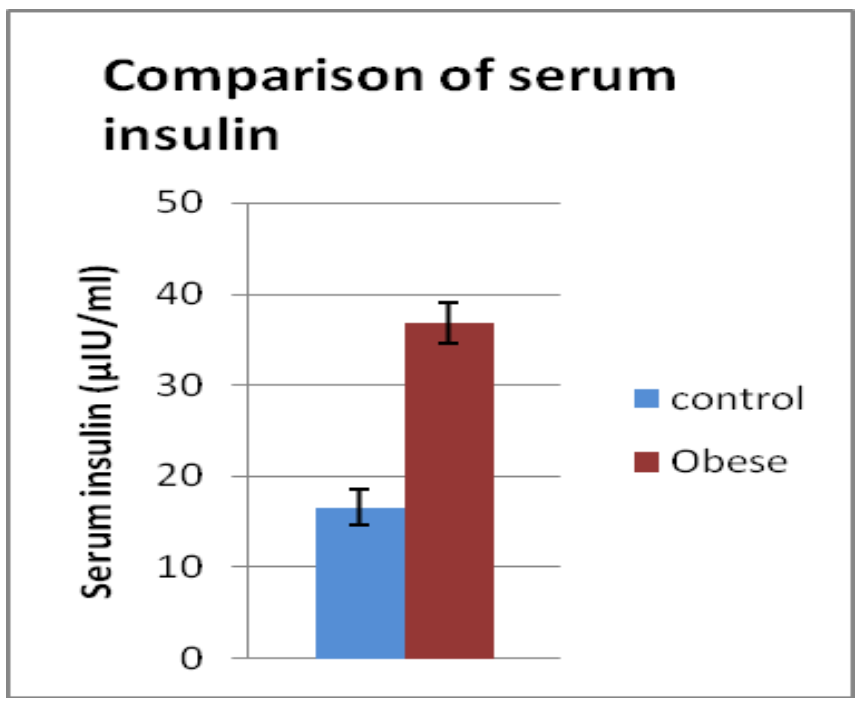

Fig3: Comparison of serum insulin based on BMI

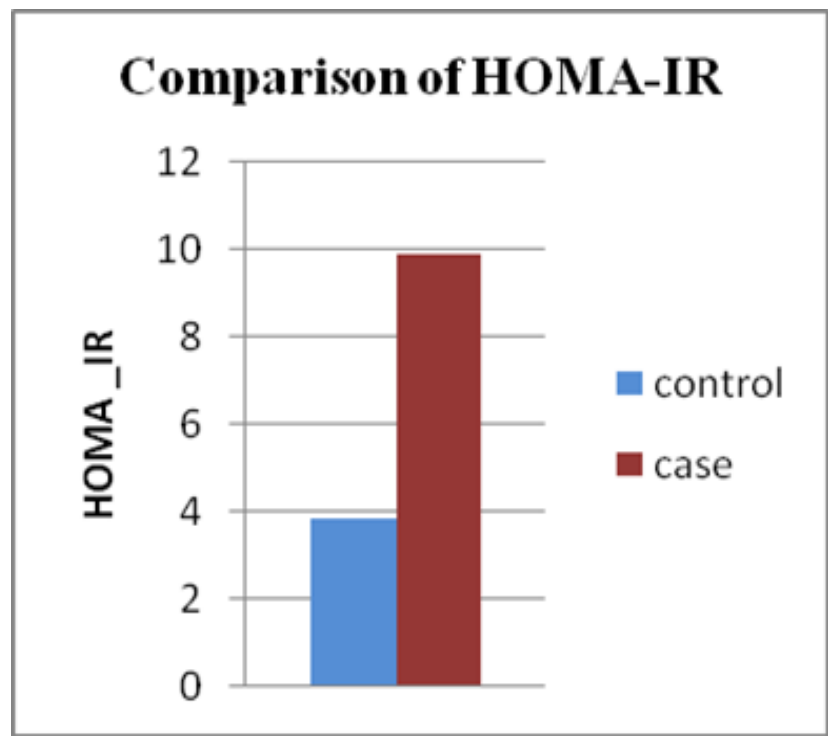

Fig5: Comparison of insulin resistance based on BMI

The difference observed in the lipids and lipoprotein levels between obese and control groups was not statistically significant. (Fig 7). Even though there was a decrease in HDL-cholesterol in

\section{Comparison of HOMA- $\beta$}

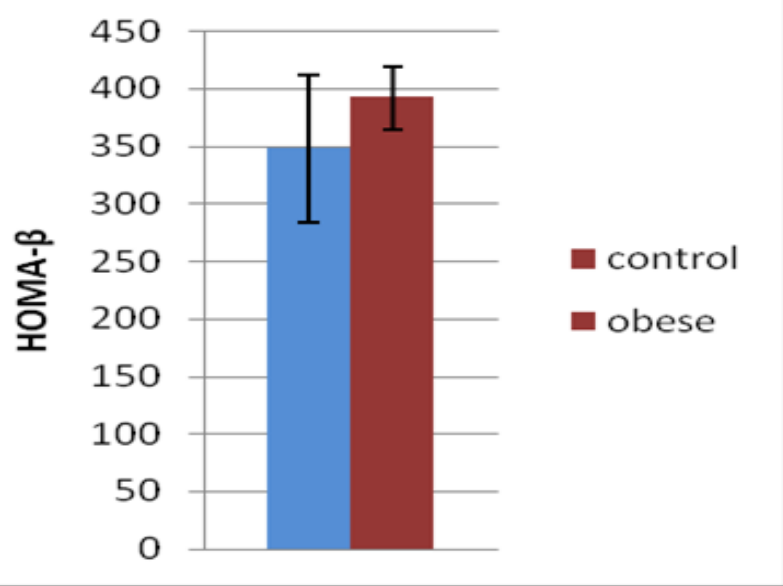

Fig4: Comparison of rate of insulin synthesis based on BMI

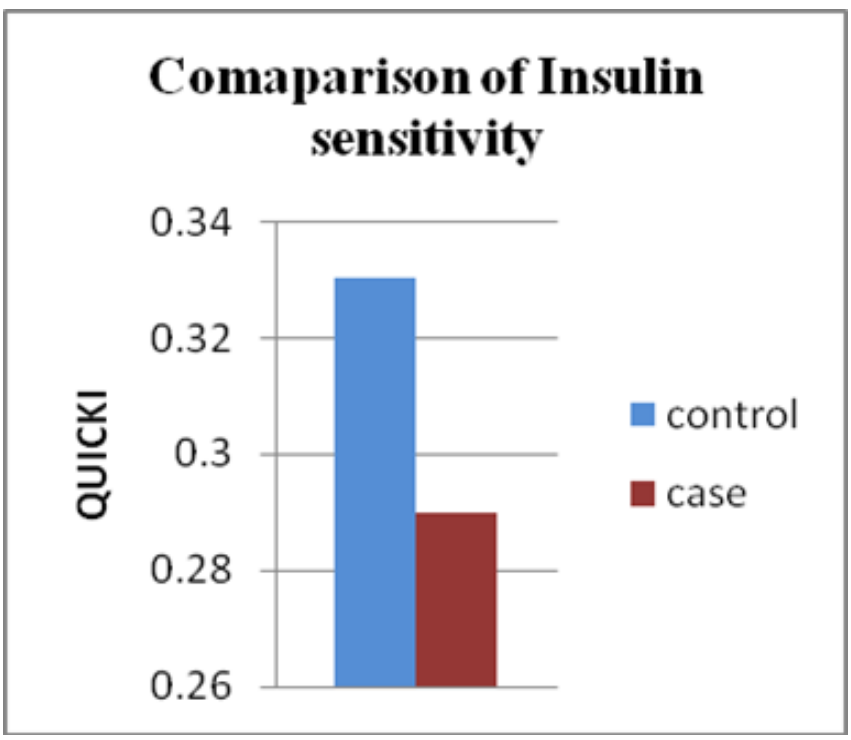

Fig6: Comparison of insulin sensitivity based on BMI

obese group (48.25 \pm 1.2$)$ in comparison with control group (52.95 \pm 1.6), the difference was not statistically significant.

\section{Comparison of lipids and lipoproteins based on BMI}

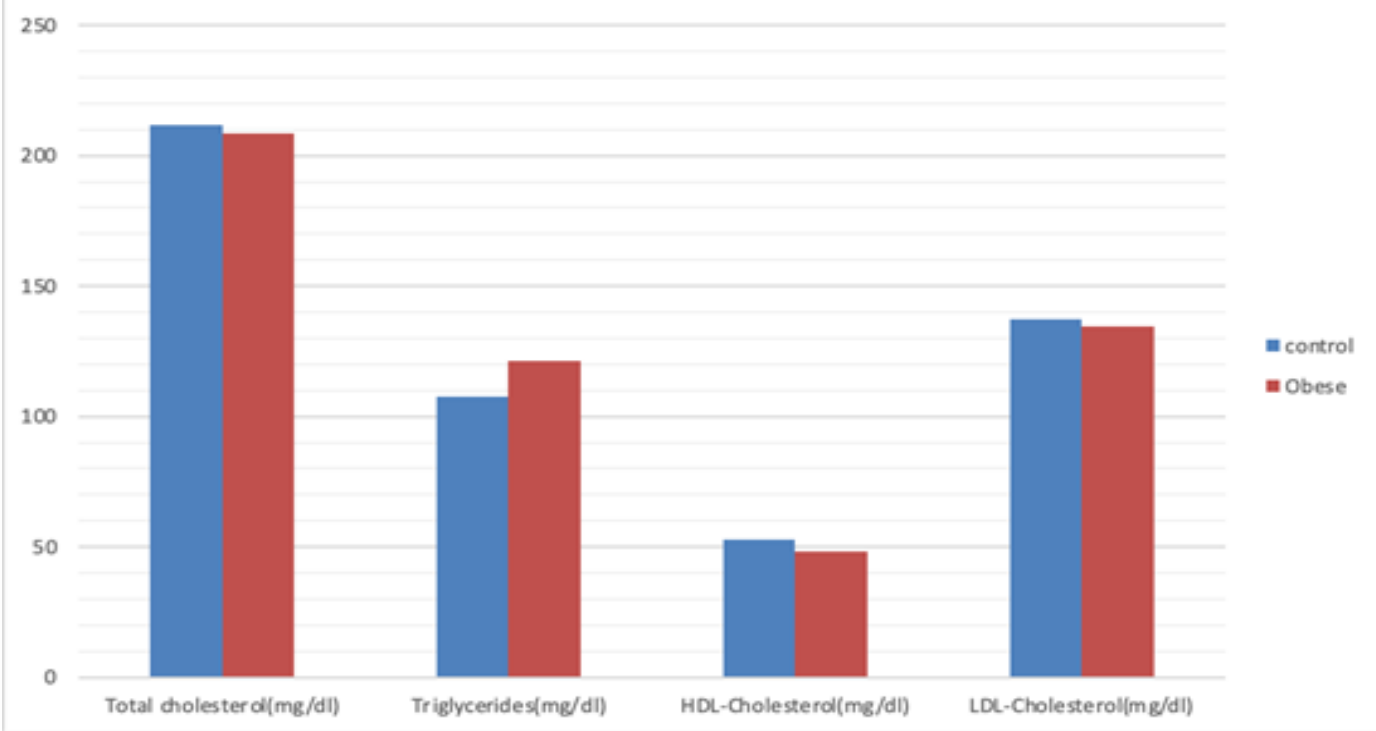

Fig7: Comparison of lipids and lipoproteins based on BMI 


\section{Discussion}

Adiponectin, the recently discovered adipocyte specific collagenlike protein is pleotropic in action targeting the liver, heart, pancreas, kidney, skeletal muscle and many other tissues to regulate insulin sensitivity, energy balance and cellular metabolism via receptor dependent mechanisms ${ }^{[8,10,13]}$. Different studies reported the central role of hypoadiponectinemia in obesity related diseases mediated by insulin resistance. The present study conducted among healthy subjects observed a negative correlation of adiponectin with BMI, waist circumference, WHR and total body fat and a positive correlation with HDL cholesterol as well as insulin sensitivity (QUICKI). This is in agreement with the study of Amit et al. in north Indian population ${ }^{[21]}$. During the correlation analysis of adiponectin with study variables, a strong negative correlation was observed with waist circumference $(r=-0.498)$ which is a better index of visceral obesity when compared with total body fat $(r=-0.337)$. This is in agreement with the study of Graciela et al. ${ }^{[3]}$. Based on a study with isolated adipocytes, Fain et al. reported that there was no difference in secretion of adiponectin from visceral or subcutaneous depots ${ }^{[22]}$. According to Motoshima et al. regulation of rate of secretion of adiponectin exhibits some depots specifically ${ }^{[23]}$. This could explain the finding that even after controlling the BMI and fat mass, individuals with higher visceral fat have lower adiponectin level than those with less visceral fat.

In our study population, the plasma adiponectin levels negatively correlated with serum insulin, insulin resistance (HOMA-IR), but positively correlated with physiological estimate of insulin sensitivity (QUICKI). But there was no significant association between serum adiponectin level and the rate of synthesis of insulin expressed as HOMA- $\beta$. This is in agreement with previous studies showing the strong relationship between plasma adiponectin levels with the components of metabolic syndrome ${ }^{[24-26]}$. According to Bacha et al. adiponectin levels accounted for $73 \%$ of variance in insulin sensitivity ${ }^{[27]}$.

Our study agrees previous findings that obesity is associated with low serum adiponectin concentrations ${ }^{[28.29]}$. In accordance with Katherine et al. our study showed a positive correlation with HDL-cholesterol ${ }^{[30]}$. The observations in our study also pointed to the significant role of adiponectin as a potent antiatherogenic and insulin sensitizing adipokine.

\section{Conclusion}

Serum adiponectin showed a positive correlation with insulin sensitivity and HDL-cholesterol. The decrease in serum adiponectin among obese subjects has been found to be associated with the development of insulin resistance. So hypoadiponectinemia may not be a major cause of obesity. Instead, it could be the result of obesity induced insulin resistance, due to decreased insulin sensitizing action of adiponectin.

\section{Ethical Approval and Consent to participate}

The study was approved by the Human Ethics Committee of both Institutions. A written informed consent was obtained from each participant.

\section{Data Availability Statement}

All the data used in writing the article are included in the manuscript

\section{Conflict of Interest}

The authors declare that there is no conflict of interest regarding the publication of this article

\section{Sources of Funding}

This research work did not receive any specific grant from any funding agencies

\section{Authors Contributions}

KTS and MKS made substantial contributions to conception and design of the study. Data collection done by MKS, LKB and VL. MKS executed the experiment. All authors participated in drafting the article and approved the content for publication.

\section{Acknowledgement}

The authors thank Mr.Jayakumar.V for performing the statistical analysis of the study. Special mention to the staff of Population Health and Research Institute, Dept. of Applied Nutrition, Govt.Medical College, Trivandrum as well as the technicians of Clinical Biochemistry Laboratory, SGMC\&RF for their help and support during data collection, sample collection and sample analysis.

\section{List of Abbreviations}

BMI: Body Mass Index

WHR: Waist to Hip Ratio

BF: Body Fat

HOMA-IR: Homeostasis Model Assessment of Insulin Resistance HOMA- $\beta$ : Homeostasis Model Assessment -beta QUICKI: Quick Insulin Sensitivity Check Index

HDL-Cholesterol: High Density Lipoprotein Cholesterol

LDL-Cholesterol: Low Density Lipoprotein Cholesterol

kD: Kilo Dalton

ELISA: Enzyme Linked Immunosorbent Assay

\section{References}

[1] Whitehead JP, Richards AA, Hickman IJ et al., Adiponectin - a key adipokine in the metabolic syndrome. Diabetes Obes Metab 2006;8:264-280.

[2] Galvani M, Scarfone A, Granato L et al., Restoration of Adiponectin Pulsatility in severely obese subjects after weight loss. Diabetes 2004;53:939-947.

[3] Graciela A Bonneau, Williams R Pedrozo, Gabriela Berg. Adiponectin and waist circumference as predictors of insulin-resistance in women. Diabetes Metab Syndr.2014;8(1):3-7.

[4] Ebrahimi-Mamaeghani M, Mohammadi S, Arefhosseini $\mathrm{SR}$ et al., Adiponectin as a potential biomarker of vascular disease. Vascular health and risk management 2015;11:55-70.

[5] Matsuda M, Shimomura I. Roles of adiponectin and oxidative stress in obesity associated metabolic and cardiovascular diseases. Reviews in Endocrine \& metabolic disorders. 2014;15(1):1-10.

[6] Maryam Esfahani, Ahmmad Movahedian, Mostafa Baranchi, et al., Adiponectin: an adipokine with 
protective features against metabolic syndrome. Iran $\mathbf{J}$ Basic Med Sci. 2015;18(5):430-442.

[7] Arunkumar E. Achari and Sushil K. Jain. Adiponectin, a Therapeutic Target for Obesity, Diabetes and Endothelial Dysfunction. Int J Mol Sci.2017;18(6):1321.

[8] Hung J, McQuillan BM, Thompson PL et al., Circulating adiponectin levels associate with inflammatory markers, insulin resistance and metabolic syndrome independent of obesity. Int J Obes.2008;32:772-779.

[9] Han SH, Sakuma I, Shin EK et al., Anti-atherosclerotic and anti-insulin resistance effects of adiponectin: basic and clinical studies.Prog Cardiovasc Dis.2009;52:126140.

[10] Bastard JP, Maachi M, Lagathu C et al., Recent advances in the relationship between obesity, inflammation, and insulin resistance. Eur Cytokine Netw. 2006;17(1):4-12.

[11] Antuna-Puente B, Feve B, Fellahi S et al., Adipokines: the missing link between insulin resistance and obesity. Diabetes Metab. 2008;34(1):2-11.

[12] Hara K, Horikoshi M, Yamauchi T et al., Measurement of the high-molecular weight form of adiponectin in plasma is useful for the prediction of insulin resistance and metabolic syndrome. Diabetes Care. 2006 Jun;29(6):1357-62.

[13] Blüher M, Brennan AM, Kelesidis T et al., Total and high-molecular weight adiponectin in relation to metabolic variables at baseline and in response to an exercise treatment program: comparative evaluation of three assays. Diabetes Care. 2007 Feb;30(2):280-5.

[14] Yamauchi T, Kamon J, Ito $\mathrm{Y}$ et al., Cloning of adiponectin receptors that mediate antidiabetic metabolic effects. Nature. 2003 Jun 12;423(6941):762-9.

[15] Blüher $\mathrm{M}$, Williams CJ, Klöting $\mathrm{N}$ et al., Gene expression of adiponectin receptors in human visceral and subcutaneous adipose tissue is related to insulin resistance and metabolic parameters and is altered in response to physical training. Diabetes Care. 2007 Dec;30(12):3110-5.

[16] Rasmussen MS, Lihn AS, Pedersen SB et al., Adiponectin receptors in human adipose tissue: effects of obesity, weight loss, and fat depots. Obesity (Silver Spring). 2006 Jan;14(1):28-35.

[17] Risch L, Guenter H, Saely C et al., Evaluation of two fully automated novel enzyme -linked immunosorbent assays for the determination of human adiponectin in serum. Clin Chem Acta 2006;373:121-6.

[18] Flier JS, Kahn CR, Roth J. Receptors, antireceptor antibodies and mechanisms of insulin resistance. $\mathrm{N}$ Eng $\mathrm{J}$ Med 1979;300(8):413-419.

[19] Matthews DR, Hosker JP, Rudenski AS, et al., Homeostasis model assessment: insulin resistance and beta-cell function from fasting plasma glucose and insulin concentrations in man. Diabetologia. 1985 Jul;28(7):412-9.

[20] Katz A, Nambi SS, Mather K, et al., Quantitative insulin sensitivity check index: a simple, accurate method for assessing insulin sensitivity in humans. J Clin Endocrinol Metab. $2000 \mathrm{Jul} ; 85(7): 2402-10$.

[21] Amit Y, Pramila J, Jain SK et al., Correlation of adiponectin and leptin with insulin resistance : A pilot study in healthy North Ondian population. Ind J Clin Biochem 2011;26(2):193-196.

[22] Fain JN, Madan AK, Hiller ML et al., Comparison of the release of adipokines by adipose tissue, adipose tissue matrix and adipocytes from visceral and subcutaneous abdominaladipose tissues of obese humans. Endocrinology 2004;145:2273-2282.

[23] Motoshima H, Wu X, Sinha MK et al., Differential regulation of Adiponectin secretion from cultured human omental and subcutaneous adipocytes: effects of insulin and Rosiglitazone. J Clin Endocrinol Metab 2002;87:5662-5667.

[24] Arita Y, Kihara S, Ouchi N et al., Paradoxical decrease of an adipose-specific protein, adiponectin, in obesity. Biochem Biophys Res Commun. 1999;257:79-83.

[25] Weyer C, Funahashi T, Tanaka $S$ et al., Hypoadiponectinemia in obesity and type 2 diabetes: close association with insulin resistance and hyperinsulinemia. J Clin Endocrinol Metab. 2001;86:1930-5.

[26] Thomas S, Suresh S, Sudheesh M, Vijayakumar T.Association of insulin resistance with adipocytokine levels in patients with metabolic syndrome.Ind $\mathrm{J}$ Clin Biochem 2015;30:155- 58.

[27] Bacha F, Saad R, Gungor N, Arslanian SA. Adiponectin in youth-relationship to visceral adiposity, insulin sensitivity and beta-cellfunction. Diabetes Care 2004;27:547-552.

[28] Yang W, Lee W J, Funahashi $T$ et al., Plasma adiponectin levels in overweight and obese Asians. Obes Res 2002;10:1104-10.

[29] Oh DK, Ciaraldi T, Henry RR. Adiponectin in health and disease. Diabetes, Obesity and Metabolism 2007;9:282289.

[30] Katherine G Meilleur, Ayo Doumatey, Hanxia Huang et al., Circulating adiponectin is associated with obesity and serum lipids in West Africans. J Clin Endocrinol Metab.2010;95(7):3517-3521.

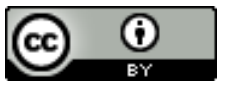

Open Access This article is licensed under a Creative Commons Attribution 4.0 International License, which permits use, sharing, adaptation, distribution and reproduction in any medium or format, as long as you give appropriate credit to the original author(s) and the source, provide a link to the Creative Commons license, and indicate if changes were made. The images or other third party material in this article are included in the article's Creative Commons license, unless indicated otherwise in a credit line to the material. If material is not included in the article's Creative Commons license and your intended use is not permitted by statutory regulation or exceeds the permitted use, you will need to obtain permission directly from the copyright holder. To view a copy of this license, visit https://creativecommons.org/licenses/by/4.0/.

(C) The Author(s) 2021 